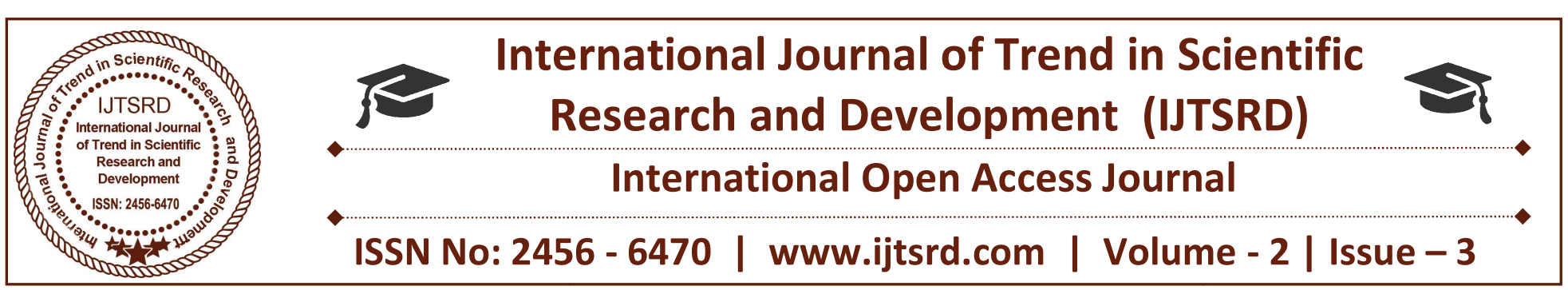

\title{
Emerging Challenging Face in Indian Banking
}

\author{
Dr. Mohan S. Rode \\ Assistant Professor \& Research Supervisor in Management, HOD in Business Studies, \\ Department of Commerce and Management Sciences, People's college Nanded, Maharashtra, India
}

\begin{abstract}
Banks now a day's plan to lay greater stress on consumer banking in the coming years, with a view to achieve higher market penetration and profitability. Technology has paved way for expanding the horizon of consumer banking and has smartened up the said business of banking. In the pre-liberalization days, banking was considered as a chore you would like to finish off as quickly as possible. Today, the scenario is totally different. Banks driven by the ever-growing competition have improvised on existing features and created new facilities that are more customers friendly. Growing Indian middle class today has a disposable surplus income and aspires for a better lifestyle. The busy business executive needs cash at any time, at all places and is willing to pay extra for this service. .New breed of financial services brand viz. Convenience banking, anywhere banking, tellbanking, branchless banking and on-line banking have appeared on the banking landscape. Most of the private and foreign banks have linked up their branches enabling a customer to operate his account from any, even from different.
\end{abstract}

\section{INTRODUCTION}

Indian banking is at cross roads today. Treat as it may sound, this characterisation is perhaps, more valid today then even before. The banking sector constitutes the core of the Indian financial system, which has been subject to far-reaching changes. Financial sector reforms programme is currently underway in view of the fact that financial intermediation is an important factor contributing both to stabilisation as well as economic growth -and

development. The basic objective of the financial sector reform in India is to promote a diversified, efficient and competitive financial system. Its aim to improving the allocative efficiency of available savings, increasing the return on investments and promoting an accelerated growth of the real sector of the economy. It also has opportunities at the cost of bigger challenges. They have to adopt new ideas in change concept in a rapid growing competition. In this process of change and adjustment, it is undoubtedly useful and indeed, necessarily to pause and undertake an assessment as to how the financial sector reforms have fared, to examine the response of banks to the rapidly changing financial environment and to identify the future course of action. For survival and growth, all banks have to adopt strategic corporate plans. Some of our more forward looking banks have given some attention to strategic planning. In preparing their strategic plans, banks need to keep some basic realities in view and for long a majority of us used to forecast $\bullet$ deposits based on a certain assumed growth rate. Banks have already started taking necessary steps to meet the challenges in the changing market environment. The future is uncertain but full of promises for Indian banks depending upon how they precede the customer's needs both present and future. With the opening up of the economy, the urgent need has emerged for greater flexibility of operations, and a more competitive environment. The Indian banking industry has responded to these changes and several new areas have been ventured into banks. Automation in the Indian banking also contributed to the adoption of and adaptability with international banking practices. The banking scene has undergone 
a sea change. It is envisaged that bank marketing in future is expected to cast a significant impact. The origin of bank marketing dates back. Marketing efforts in Indian public sector banks has almost been a non-starter. This marketing approach has been started by private sector and foreign banks in Indian market, due to which 'service' has became important as an aspect in banking sector. Commercial banks are forced to accept the change approach and difficult for them, to survive in the market. A drastic change took place in banking Industry. Due to which customer' service acquires crucial significance in the context of sustained business growth. Modem technology has made customer aware of the developments in the economic environment including the financial system with a wide network of branches, even in a dissimilar banking scenario, customers expect the banks to offer more and better services to match their demands and this has compelled banks to take up marketing in right earnest.

\section{Banking Then and Now}

In the earliest stages of man's economic civilization, in the absence of money, the transactions relating to exchange of goods were based on the barter system. "Barter" means exchange of goods i.e. goods exchanged against goods. Thus one has to give some kind of goods to get some other kind of goods. There is no use of money or any medium of exchange in barter economy. Thus barter economy is money less economy.

As the economy moves ahead, the money as a mode of exchange came into existence. Henceforth money becomes mode of exchange. It is the mode of exchanges and gains importance in socio-economic culture of the country. Slowly moneylenders came in to existence, then institutions ' started to lend the money. Due to which importance of transactions, money, goods has become primary base, institutions like bank, financial institution started to play their roles in the economy.

Bank plays an important increasing role in a nations economy, occupying a pivotal Position in the organised market .it is a profit-seeking business firm, dealing in money and credit, it is a financial institutions dealing in money in the sense that it accepts deposits of money from public to keep \&?em in its custody for safety. So it also deals in credit, i.e.
It creates credits by making advances out of funds received as deposits to needy people. It has acquired a special place with its large network of branches, and with its huge deposits and advances. The long process of expansion, regulation and re-organisation of banking can be elaborately dealt with. With the gradual change in the very concept of banking and with the entry of state in its administration, banking has assumed enormous importance as a subject of analysis and research.

Banking industry in India during the course of its evolution and growth are passing a phase of transformation \& traversed through innumerable twists and turns, With the advent of banking sector reforms, the scenario of banking in the 1990s has totally changed. Banks now operate in a situation of keen competition in their financial service activities, whether it is canvassing of deposits, extending credit line or in selling ancillary services. In such a competitive environment, the ability of a bank even to sustain its growth rate depends on how well the needs of customers are identified and effective marketing strategies are evolved. This involves developing new and improved products and services, providing better amenities and facilities. Banks, irrespective of their size, have been increasingly focusing on retail segment for both resources mobilization and lending. Banks-privately owned or in the public sector-have all jumped into retail bandwagon. That the banking industry has embraced a retail culture.

\section{Objectives of the Study}

The following are the main objectives of the study.

1. To study the agewise Satisfaction Level of Customers.

2. To examine the accountwise Satisfaction Level of Customers.

3. To study the periodwise Satisfaction Level of Customers.

4. To examine the Incomewise Satisfaction Level of Customers.

5. To study the Occupationwise Satisfaction Level of Customers.

6. To examine the changing scenario in banks.

7. To concentrate on facts \& challenges ahead' for the banking. 
To study the modem banking concept based on marketing and service oriented.

\section{METHODOLOGY OF THE STUDY}

\section{a) Statement of Problem}

All the private banks are providing various services to their accountholders. They have different service charges and different types of accounts to cater to the needs of their customers. Naturally, customer will expects higher level of services from bank's staff, because they are paying for that. The reason for selecting this topic is thus to compare the percentage of all the different level service provided in the bank, to give suggestion to improve the service level in order to maintain accounts of customer with same banks. Not to divert their account to other bank. And to welcome suggestion from customer to improve customer service \&customer friendly atmosphere. This helps the bank to maintain and to increase the number of accounts in their bank. This can be possible only when changes in their products in order to compete even with other sophisticated private banks.

\section{b) Source of Data}

The study is based on primary and secondary data. Primary data was collected from customer of bank having their account. (Development Credit Bank Mumbai, with reference to Marathwada Region Branches at Nanded and Aurangabad) by filling up well structured questionnaire and through personal meeting with customers. Secondary data was collected from different brochures, IBA bulletin, websites of banks, magazines and journals.

\section{c) Research Approach}

To collect the primary data "Survey research approach" was adopted for the project and for this communication, approach personal interview of the respondent was conducted.

\section{d) Research Instrument}

For the collection of primary data, properly structured questionnaire was used. The questionnaire comprises of both closed ended and open ended questions. In case of close-ended question, check list, likert scales have been included.

\section{e) Sampling Process}

The sample was selected for the present study of customers in Development Credit Bank Ltd. (DCB) in Marathwada region. As branches are only two (Nanded and Aurangabad).

Customer base accountholders (savings account, current account. Fixed Deposit account etc.) Comes 16,000 each approximately at Nanded and Aurangabad. The above 1 percentage accountholders are randomly selected for the study, from this 320 accountholders are selected on the basis of types of accounts 40 each are as follows in table no. 2 .

It is not feasible to go for a population survey due to this numerous account holders (customers). Hence, intelligent sampling has been adopted.

\section{f) Limitations of the Study:}

Due to time and cost factor only 320 customers were survey.

The study is limited to Marathwada Region only (Nanded and Aurangabad)

All the information furnished by the respondents was treated as correct

\section{ANALYSIS AND INTERPRETATION OF DATA}

The collected primary data to be interpreted on the above parameters i.e. Age, Income of Customers, Occupation, Nature of Account, Banking since (Period) which has directly co-related with questionnaire. The above parameters co-related by preparing table for measuring the level of satisfaction from services. The above parameters are presented in a taubular form by applying chi-square test. 
TABLE NO. 1 AGEWISE SATISFACTION LEVEL OF CUSTOMERS

\begin{tabular}{|l|l|l|l|l|l|}
\hline \multirow{2}{*}{ Age } & \multicolumn{2}{|c|}{ Premises/Ambience } & \multirow{2}{*}{ Total } \\
\cline { 2 - 5 } & $\begin{array}{l}\text { Highly } \\
\text { Satisfied }\end{array}$ & Satisfied & Dissatisfied & Neutral & \\
\hline $018-45$ & 6 & 148 & 52 & 18 & 224 \\
\hline $45-60$ & 2 & 38 & 28 & 18 & 86 \\
\hline $60-$ Above & --- & 8 & 2 & -- & 10 \\
\hline Total & 08 & 194 & 82 & 36 & 320 \\
\hline
\end{tabular}

\section{Source: Primary Data}

\begin{tabular}{|l|c|c|c|}
\hline Chi - Square Test & Value & DF & Asymp. Sig. (2 Sided) \\
\hline $\begin{array}{l}\text { Pearson } \\
\text { Chi }- \text { Square }\end{array}$ & 18.428 & 6 & 0.005 \\
\hline
\end{tabular}

4 Cells $(33.3 \%)$ have expected count less than 5. The minimum expected count is 0.25 .

The table no.5.1 indicates that the highlights on agewise satisfaction level of customers for Premises / Ambience. The total number of samples are 320 . From age group $18-45$ are 224 customers, age group 45-60 are 86 customers, age group 60-above are 10 customers. From this samples highly satisfied customers are 8, satisfied customers are 194 dis- satisfied, customers are 82 , and neutral customers are 36.

By applying chi-square test of Karl Pearson on above computed value is 18.428 , degree of freedom is 6 and given value/assumed value 2 (sided) is 0.005 . As computed value is greater than assumed value null hypothesis is rejected. It may conclude that satisfaction level of premises/ambience is independent of different age group.

TABLE NO. 2 ACCOUNTWISE SATISFACTION LEVEL OF CUSTOMERS

\begin{tabular}{|l|l|l|l|l|l|}
\hline \multirow{2}{*}{ Nature of A/c } & \multicolumn{3}{|c|}{ Premises - Ambience } & \multirow{2}{*}{ Total } \\
\cline { 2 - 5 } & Highly Satisfied & Satisfied & Dissatisfied & Neutral & \\
\hline SB/C & 04 & 60 & 10 & 06 & 80 \\
\hline SB/P & --- & 60 & 04 & 16 & 80 \\
\hline CA/C & -- & 30 & 38 & 12 & 80 \\
\hline CA/P & 04 & 44 & 30 & 02 & 80 \\
\hline Total & 08 & 194 & 82 & 36 & 320 \\
\hline
\end{tabular}

\section{Source: Primary Data}

\begin{tabular}{|l|l|l|l|}
\hline Chi - Square Test & Value & DF & Asymp. Sig. (2 Sided) \\
\hline $\begin{array}{l}\text { Pearson } \\
\text { Chi }- \text { Square }\end{array}$ & 71.817 & 9 & 0.000 \\
\hline
\end{tabular}

The table no.5.17 indicates that the highlights on accountwise satisfaction level of customers for Premises / Ambience. The total numbers of samples are 320. From Nature of Account $\mathrm{SB} / \mathrm{C}$ are 80 customers, Nature of Account $\mathrm{SB} / \mathrm{P}$ are 80 customers, Nature of Account $\mathrm{CA} / \mathrm{C}$ are 80 customers, Nature of Account $\mathrm{CA} / \mathrm{P}$ are 80 customers, From this samples highly satisfied customers are 8, satisfied customers are 194, dissatisfied customers are 82, and neutral customers are 36. 
By applying chi-square test of Karl Pearson on above computed value is 71.817 , degree of freedom is 9 and given value/assumed value 2 (sided) is 0.000 . As computed value is greater than assumed value null hypothesis is rejected. It may conclude that satisfaction level of premises/ambience is independent of different Nature of Account.

TABLE NO.3 PERIODWISE (BANSINC) SATISFACTION LEVEL OF CUSTOMERS

\begin{tabular}{|l|l|l|l|l|l|}
\hline \multirow{2}{*}{ Bansinc } & \multicolumn{4}{|c|}{ Premises - Ambience } & \multirow{2}{*}{ Total } \\
\cline { 2 - 6 } & Highly Satisfied & Satisfied & Dissatisfied & Neutral & \\
\hline Less than 10 years & 6 & 174 & 66 & 30 & 276 \\
\hline $\begin{array}{l}10 \text { Years to less than 20 } \\
\text { years }\end{array}$ & 2 & 20 & 16 & 06 & 44 \\
\hline Total & 8 & 194 & 82 & 36 & 320 \\
\hline
\end{tabular}

Source: Primary Data

\begin{tabular}{|l|c|c|c|}
\hline \multicolumn{1}{|c|}{ Chi - Square Test } & Value & DF & Asymp. Sig. ( 2 Sided) \\
\hline Pearson & 5.344 & & 0.148 \\
Chi - Square & & &
\end{tabular}

2 Cells $(25.0 \%)$ have expected count less than 5 . The minimum expected count is 1.10 .

The tableno.5.33 indicates that the highlights on periodwise satisfaction level of customers for Premises/Ambience. The total numbers of samples are 320. From bansinc less than 10 years are 276 customers, 10 years to less than 20 years are 44 customers. From this samples highly satisfied customers are 8, satisfied customers are 194, dis-satisfied customers are 82, and neutral customers are 36.

By applying chi-square test of Karl Pearson on above computed value is 5.344, degree of freedom is 3 and given value/assumed value 2 (sided) is 0.148 . As computed value is greater than assumed value null hypothesis is rejected. It may conclude that satisfaction level of premises/ambience is independent of different bansinc.

TABLE NO.4 INCOMEWISE SATISFACTION LEVEL OF CUSTOMERS

\begin{tabular}{|l|c|c|c|c|c|}
\hline \multirow{2}{*}{$\begin{array}{c}\text { Income of } \\
\text { Customer }\end{array}$} & \multicolumn{3}{|c|}{ Premises-Ambience } & \multirow{2}{*}{ Total } \\
\cline { 2 - 6 } & $\begin{array}{c}\text { Highly } \\
\text { Satisfied }\end{array}$ & Satisfied & Dissatisfied & Neutral & \\
\hline Upto 1 Lac & 02 & 12 & 02 & --- & 16 \\
\hline 1 Lac to 2 Lacs & --- & 14 & 02 & 06 & 22 \\
\hline 2 Lacs to 3 Lacs & --- & 32 & 12 & 08 & 52 \\
\hline 3 Lacs and above & 06 & 136 & 66 & 22 & 230 \\
\hline Total & 08 & 194 & 82 & 36 & 320 \\
\hline
\end{tabular}

Source: Primary Data

\begin{tabular}{|l|c|c|c|}
\hline \multicolumn{1}{|c|}{ Chi - Square Test } & Value & DF & Asymp. Sig. ( 2 Sided) \\
\hline $\begin{array}{l}\text { Pearson } \\
\text { Chi }- \text { Square }\end{array}$ & 21.523 & 9 & 0.011 \\
\hline
\end{tabular}


6 Cells $(37.5 \%)$ have expected count less than 5 . The minimum expected count is 0.40 .

The tableno.5.25 indicates that the highlights on incomewise satisfaction level of customers for Premises/Ambience. The total number of samples are 320. From Income of Customer upto1 Lac are 16 customers, 1 Lac to 2 Lacs are 22 customers, 2 Lacs and 3 Lacs are 52 customers, and 3 lacs and above are 230 customers From this samples highly satisfied customers are 8, satisfied customers are 194 dis-satisfied customers are 82, and neutral customers are 36.

By applying chi-square test of Karl Pearson on above computed value is 21.523, degree of freedom is 9 and given value/assumed value 2 (sided) is 0.011 . As computed value is greater than assumed value null hypothesis is rejected. It may conclude that satisfaction level of premises/ambience is independent of different Income of Customer.

\section{TABLE NO.5 OCCUPATIONWISE SATISFACTION LEVEL OF CUSTOMERS}

\begin{tabular}{|l|l|l|l|l|l|}
\hline \multirow{2}{*}{ Occupation } & \multicolumn{2}{|c|}{ Premises-Ambience } & \multirow{2}{*}{ Total } \\
\cline { 2 - 6 } & $\begin{array}{l}\text { Highly } \\
\text { Satisfied }\end{array}$ & Satisfied & Dissatisfied & Neutral & \\
\hline Service & 02 & 38 & 08 & 12 & 60 \\
\hline Professional & -- & 02 & -- & 02 & 04 \\
\hline Self Empl. & -- & 04 & 02 & --- & 06 \\
\hline Businessmen & 06 & 146 & 70 & 20 & 242 \\
\hline Others & -- & 04 & 02 & 02 & 08 \\
\hline Total & 08 & 194 & 82 & 36 & 320 \\
\hline
\end{tabular}

Source: Primary Data

\begin{tabular}{|l|l|l|l|}
\hline \multicolumn{1}{|c|}{ Chi - Square Test } & \multicolumn{1}{|c|}{ Value } & DF & Asymp. Sig. (2 Sided) \\
\hline $\begin{array}{l}\text { Pearson } \\
\text { Chi - Square }\end{array}$ & 20.044 & 12 & 0.066 \\
\hline
\end{tabular}

3 Cells $(65.0 \%)$ have expected count less than 5 . The minimum expected count is 0.10 .

The table no.5.9 indicates that the highlights on occupation wise satisfaction level of customers for Premises / Ambience. The total numbers of samples are 320. From Occupation group such as service customers are 60, Professional customers are 04, Self employed customers are 06, Businessmen customers are 242, and others categories customers are 8. From this samples highly satisfied customers are 8, satisfied customers are 194, dis-satisfied customers are 82 , and neutral customers are 36.

By applying chi-square test of Karl Pearson on above computed value is 20.044 , degree of freedom is 12 and given value/assumed value 2 (sided) is 0.066 . As computed value is greater than assumed value null hypothesis is rejected. It may conclude that satisfaction level of premises/ambience is independent of different Occupation.

\section{FINDINGS \& SUGGESTION}

From percentage of satisfied it is found that customers are dual-mind, they want the premises must be clean, specious, easy to move there, and sitting, arrangement to aged - people so as to fell them comfortable in operation the accounts.

$>$ The behavior and attitude of staff towards customer must responsive, as they should feel them a VIP customer of our bank.

$>$ The customer services received at counter must be friendly and promptly. To avoid the feelings of other bank will give the best services compared with this bank.

$>$ Others services like marketing representative, ATM, product and service. Guidance facilities 
must be competitive to increase the highly satisfied level. The bank must provide at best for that modern advance technology must be adopted.

$>$ Customer meets to be taken to make proper understanding \& solving problems between staff and customer so as to remove hurdles and to increase service level at highly satisfied.

$>$ From overall comparison it is found that when we are serving to customers, we have to take care as compared to competitive market and serving the service they should feel that there is no any other bank to give best service in retail banking. Resulted increase in profit percentage of account opening will also increase and good relationship in maintaining earlier accounts. Due to above a good image will be created in the minds of customers in the market. As per the research study, undertaken it is observed that the percentage of highly satisfied in all service is very low compared to satisfied. That should be changed into vice-versa by providing good customer services with the help of customer orientation programme.

$>$ This in turn, will increase the flow of funds, new accounts, maintain the accounts of customer in friendly manner which creates the good image in the market for retail business in banking.

\section{CONCLUSION}

With the liberalisation wave sweeping the economy in general and the financial sector in particular, the Indian banking scenario will undergo change in the near future. This change will be characterised by the presence of more foreign and private sector banks, increased capital market activities and new financial products in the market. In brief, the future banking scenario will be marked by fierce competition, a higher level of customers' expectations, more thrust on technological up gradation and the emergence of innovative products and services. Consequently, banks have to prepare themselves to face the market fundamentals effectively. How can the banks cope with managing the change in the emerging market driven environment? Perhaps, the answer lies in maintaining a high service quality. To maintain high service quality, banks have to come closer to their customers to monitor and to react to the pace of change in their needs and expectations and devise effective ways to meet or exceed them. Thus, in order to find the services provided by the bank which in turns helps the bank to improve and the bank can provide the customer's the best services. The Peak Performance programmes will show you and your team not only how to achieve the culture change, but also the steps to take in order to become an organization which values and exhibits "Customers Service Excellence".

\section{REFERENCES}

1. Almeida, R. A. 2003. IBABull. XXV, pp 11.

2. Choudhary, C. M. 1996. Financial Sector Reforms in India, Sublime Publications, Jaipur

3. Dasgupta, B. 2005. Globlalisaiton India's Adjustment Experience, Saga Publication, New Delhi

4. Kotler, P. 2003. Marketing Management, Pearson Education, New Delhi

5. Mathur, B.L.2005. Financial Sector Reforms, RBSA Publications, Jaipur

6. Murali, S.; Lakshminarasirnha, A. 2005. IBABull. XXVII (5)

7. Parameswaran, M. G,2003. Understanding Consumers, Tata Mc Craw-Hill Publishing company Limited, New Delhi.

8. Rama Krishnan, K., 2006. Cover Story Indian ; Banker, I (II)

9. Saxena.R.,2002. Marketing Management Tata Mc-GrW Hill. 